\title{
THE
}

4-29-2014

\section{Crustal Velocity Structure of the Northeastern Tibetan Plateau from Ambient Noise Surface-Wave Tomography and its Tectonic Implications}

\author{
Xinfu Li \\ Hongyi Li \\ Yang Shen \\ University of Rhode Island, y.shen@icloud.com \\ Meng Gong \\ Danian Shi
}

See next page for additional authors

Follow this and additional works at: https://digitalcommons.uri.edu/gsofacpubs

Terms of Use

All rights reserved under copyright.

\section{Citation/Publisher Attribution}

Li, Xinfu; Li, Hongyi; Shen, Yang; Gong, Meng; Shi, Danian; Sandvol, Eric; Li, Aibing. (2014). "Crustal velocity structure of the northeastern Tibetan Plateau from ambient noise surface-wave tomography and its tectonic implications." Bulletin of the Seismological Society of America. 104(3): 1045-1055.

Available at: http://dx.doi.org/10.1785/0120130019

This Article is brought to you for free and open access by the Graduate School of Oceanography at DigitalCommons@URI. It has been accepted for inclusion in Graduate School of Oceanography Faculty Publications by an authorized administrator of DigitalCommons@URI. For more information, please contact digitalcommons-group@uri.edu. 
Authors

Xinfu Li, Hongyi Li, Yang Shen, Meng Gong, Danian Shi, Eric Sandvol, and Aibing Li

This article is available at DigitalCommons@URI: https://digitalcommons.uri.edu/gsofacpubs/113 


\title{
Crustal Velocity Structure of the Northeastern Tibetan Plateau
}

\author{
from Ambient Noise Surface-Wave Tomography \\ and Its Tectonic Implications
}

\author{
by Xinfu Li, Hongyi Li, 'Yang Shen, Meng Gong, Danian Shi, Eric Sandvol, and Aibing Li
}

\begin{abstract}
Broadband seismic data from the regional seismic network operated by the China Earthquake Administration and 32 temporary seismic stations are used to image the crustal velocity structure in the northeast Tibetan plateau. Empirical Rayleigh- and Love-wave Green's functions are obtained from interstation cross correlation of continuous seismic records. Group velocity dispersion curves for Rayleigh and Love waves between 10 and $50 \mathrm{~s}$ are obtained using the multiple-filter analysis method with phasematched processing. The group velocity variations of Rayleigh and Love waves overall correlate well with the major geologic structures and tectonic units in the study region. Shear-wave velocity structures were then inverted from Rayleigh- and Love-wave dispersion maps. The results show that the Songpan-Ganzi terrane is associated with a low velocity at depth greater than $20 \mathrm{~km}$. The northern Qilian orogen, with higher elevation and thicker crust compared to the southern Qilian orogen, is also dominated by low velocity at depth greater than $\sim 25 \mathrm{~km}$. However, there is no clear evidence of the low-velocity mid-to-lower crust beneath the southern Qilian orogen as the crustal flow model predicts. The low-velocity zone (LVZ) beneath the northern Qilian orogen may suggest that the crustal thickening and surface uplift of the northern Qilian orogen are related to the LVZ, and the LVZ may be considered as an intracrustal response to bear the ongoing deformation in the northern Qilian orogen.
\end{abstract}

Online Material: Figures of crustal topography, number of group velocity measurements, checkerboard tests for NETS stations, and 1D velocity models.

Introduction

The Tibetan plateau has been the prime site for understanding the processes of continental collision, mountain building, and the interaction between tectonics and climate change. The collision between the Indian and Eurasian plates not only has caused significant elevation and highly deformed orogenic belts within the Tibetan plateau, but also impacts remote areas such as eastern China and the Baikal rift to the north (Molnar and Tapponnier, 1975; Tapponnier and Molnar, 1977; Bendick and Flesch, 2007). Many studies have been performed in the Tibetan plateau, but most of the geophysical studies of the Tibetan crust and mantle structure to date have focused on the southern (Brown et al., 1996; Kind et al., 1996; Nelson et al., 1996; Huang et al., 2000; Wei et al., 2001; Wang et al., 2003; Unsworth et al., 2005; Yao et al., 2008; Guo et al., 2009), central (Owens and Zandt, 1997; Kind et al., 2002; Tilmann et al., 2003), and eastern Tibetan plateau (Li

\footnotetext{
*Also at School of Geophysics and Information Technology, China University of Geosciences, Beijing, 100083, China.
}

et al., 2009), with the primary objectives of understanding the continental collision process and the intrusion of the crustal and mantle materials from the Indian plate into the Eurasian plate. In comparison to other parts of the plateau, fewer seismic investigations have been done in the northeastern Tibetan plateau (e.g., Wittlinger et al., 1996; Zhu and Helmberger, 1998; Vergne et al., 2002, 2003; Karplus et al., 2011, 2013; Yue et al., 2012), which either are localized along linear profiles or focused on the velocity discontinuity structure. In our previous study (Li et al., 2012), we determined that the lowvelocity zone (LVZ) terminated around the east Kunlun fault (KLF) in the northeastern Tibetan plateau. However, due to the coarse resolution $\left(1.6^{\circ}\right)$ and lack of data (we only used data from the China Provincial Digital Seismic Networks, Kyrgyzstan network, and Kazakhstan network), we did not resolve any features in the Qilian orogen. In this study, we complemented the data from the China Earthquake Networks Center with the northeastern Tibet seismic experiment (Shen et al., 2008). These additional broadband, passive-source seismic 
(a)

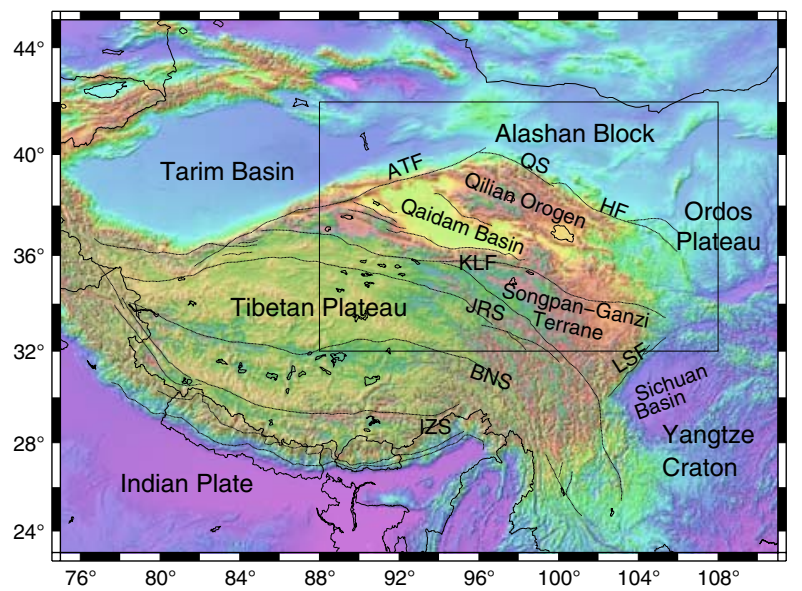

(b)

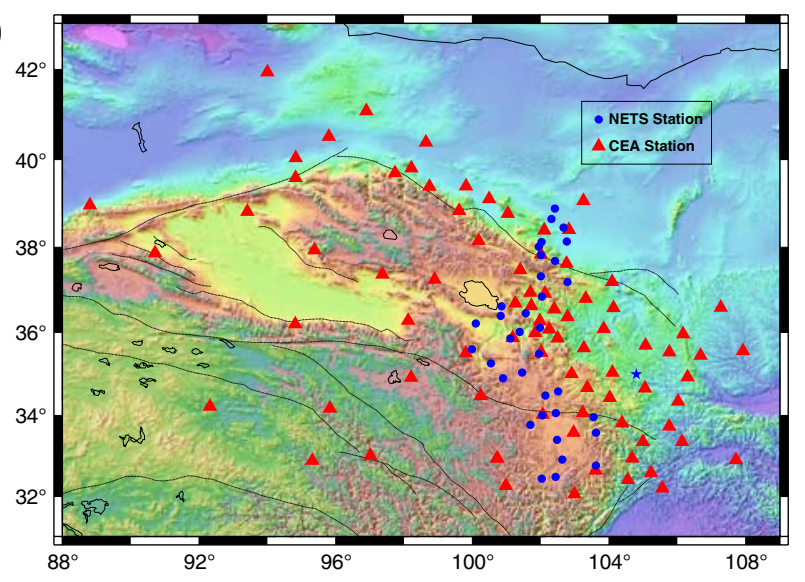

Figure 1. (a) Topographic relief of the Tibetan plateau and adjacent areas and (b) the distribution of seismic stations used in this study. Dashed lines mark tectonic elements. The rectangle in (a) indicates the study area. ATF, Altyn-Tagh Fault; QS, Qinling Suture; HF, Haiyuan Fault; KLF, KunLun Fault; JRS, Jinsha-River Suture; BNS, Bangong-Nujiang Suture. In (b), the triangles are seismic stations belonging to the Seismic Network of Gansu Province and the Chinese center of Digital Seismic Network (CCDSN). The solid circles are the stations of northeast Tibet seismic (NETS) array from June 2008 to July 2010 . The star denotes the location referred to in Figure 7. The color version of this figure is available only in the electronic edition.

experiments were designed to investigate the lithospheric structure and evolution of the northeastern Tibetan plateau (Fig. 1) and contributed additional high-quality data to resolve the structure under the northeastern portion of the Tibetan plateau.

The deformation process of the Tibetan plateau is generally attributed to a series of collision events (Molnar et al., 1993; Owens and Zandt, 1997; Tapponnier et al., 2001; Chung et al., 2005; Dai et al., 2011). The deformation mechanism of the Tibetan plateau and its adjacent regions may be characterized by several models of collision between India and Eurasia, such as a unidirectional underthrust model and bidirectional subduction model. In the unidirectional underthrust model, the Indian lithosphere subducts northward, the Songpan-Ganzi oceanic lithosphere was subducted northward beneath the Kunlun blocks (Powell and Conaghan, 1975; Molnar et al., 1993; Yin and Harrison, 2000), and the Qaidam basin acted as an obstacle (Zhao and Morgan, 1985; Yin and Harrison, 2000). In the bidirectional subduction model, in addition to this northward subduction, the Tarim basin and the Qaidam basin lithospheres are being subducted southward (Pearce and Mei, 1988; Arnaud et al., 1992; Xu, 1992; Deng, 1997; Tapponnier et al., 2001; Kind et al., 2002; C. Zhang et al., 2010; Z. Zhang et al., 2010; Q. Zhang et al., 2011; Z. Zhang et al., 2011). Aside from these two models, some studies suggest that the stronger Indian plate is embedded in the Tibetan plateau and the force of collision leads to the lateral escape of the plateau materials toward the southeast and the east along a series of strike-slip faults (e.g., Molnar and Tapponnier, 1975; Tapponnier and Molnar, 1977). Tapponnier et al. (2001) suggested an oblique crustal subduction accommodated by the extrusion tectonics to be the mechanism of the growth and uplift of the eastern Tibetan plateau. However, other researchers (e.g., Royden et al., 1997, 2008; Clark and Royden, 2000; Clark et al., 2005) consider that the lower crustal flow may be responsible for the different topographic profiles at the different margins of the Tibetan plateau. Low-velocity and lowresistivity materials have been observed beneath the eastern Tibetan plateau (Li et al., 2009; Bai et al., 2010), but geophysical evidence of the proposed flow paths remains to be found in the northeast Tibetan plateau.

In this study, we focus on a complex junction that connects the margin of the Tibetan plateau with the Tarim basin, Sichuan basin, Ordos plateau, and Alashan block (Fig. 1), where 32 temporary broadband stations were deployed between June 2008 and July 2010 (Shen et al., 2008). Our study area contains the northeast Tibetan plateau, the Songpan-Ganzi terrane, the Qilian orogen, and the Alashan block, which are separated by the Haiyuan fault (HF) system and Qinling suture (QS) in the north and the KLF system and the Qaidam basin in the south (Fig. 1). The convergence in the northeast Tibetan plateau has been accommodated by the left lateral strike-slip motion (with a slip rate of $\sim 12 \mathrm{~mm} / \mathrm{yr}$ ) along the KLF (e.g., Tapponnier et al., 2001; Wang et al., 2001; Zhang et al., 2004). Therefore, this region is very suitable to study the mechanisms responsible for the rising of the Tibetan plateau and the role of the KLF in accommodating the convergence of the India-Asia collision.

In this article, we apply the ambient noise method to the northeastern Tibetan plateau to obtain a high-resolution crustal velocity structure. Three-component time series, recorded at 81 broadband stations of Provincial Digital Seismic Networks and 32 broadband stations deployed by China University of Geosciences in Beijing, Chinese Academy of Geological Sciences, University of Rhode Island, University of Houston, and University of Missouri between June 2008 and July 2010, are cross correlated to estimate both Rayleigh- and Love-wave Green's functions. The resulting group velocity maps have resolutions on the order of $\sim 100 \mathrm{~km}$ in most parts of the northeast Tibetan plateau and generally show good correlations with major geologic and tectonic units in the study region. We invert shear-wave velocity 
(a)

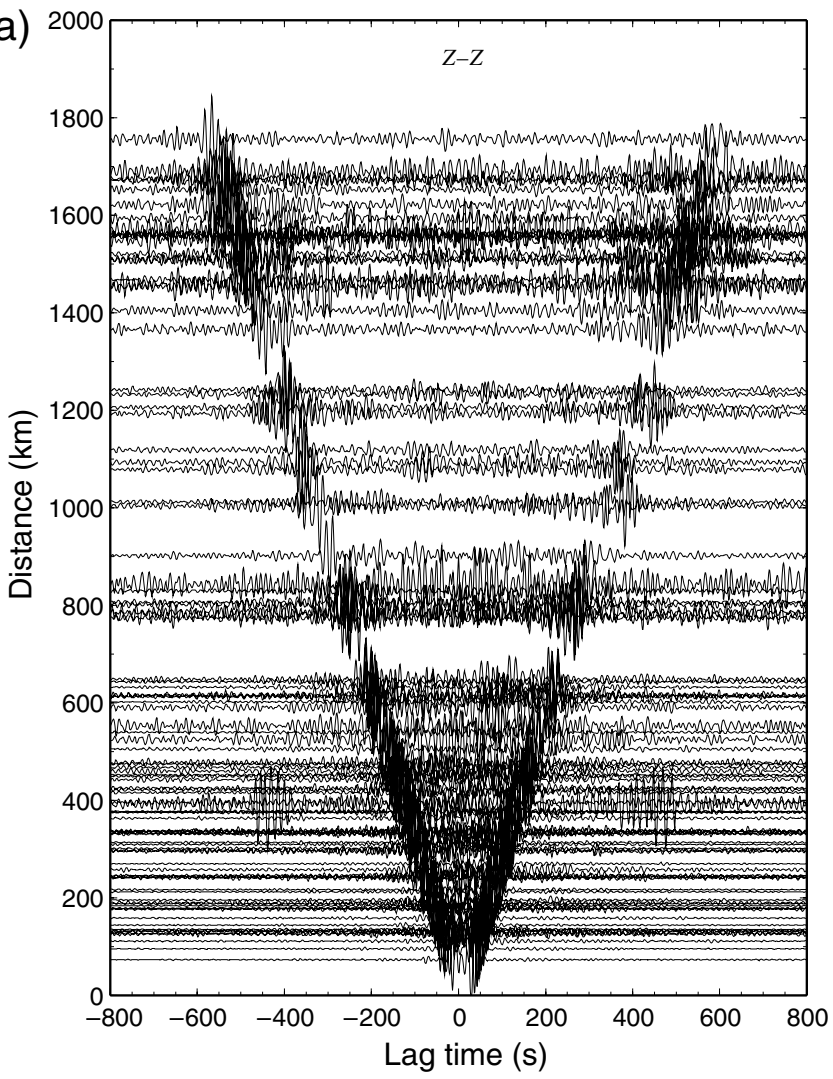

(b)

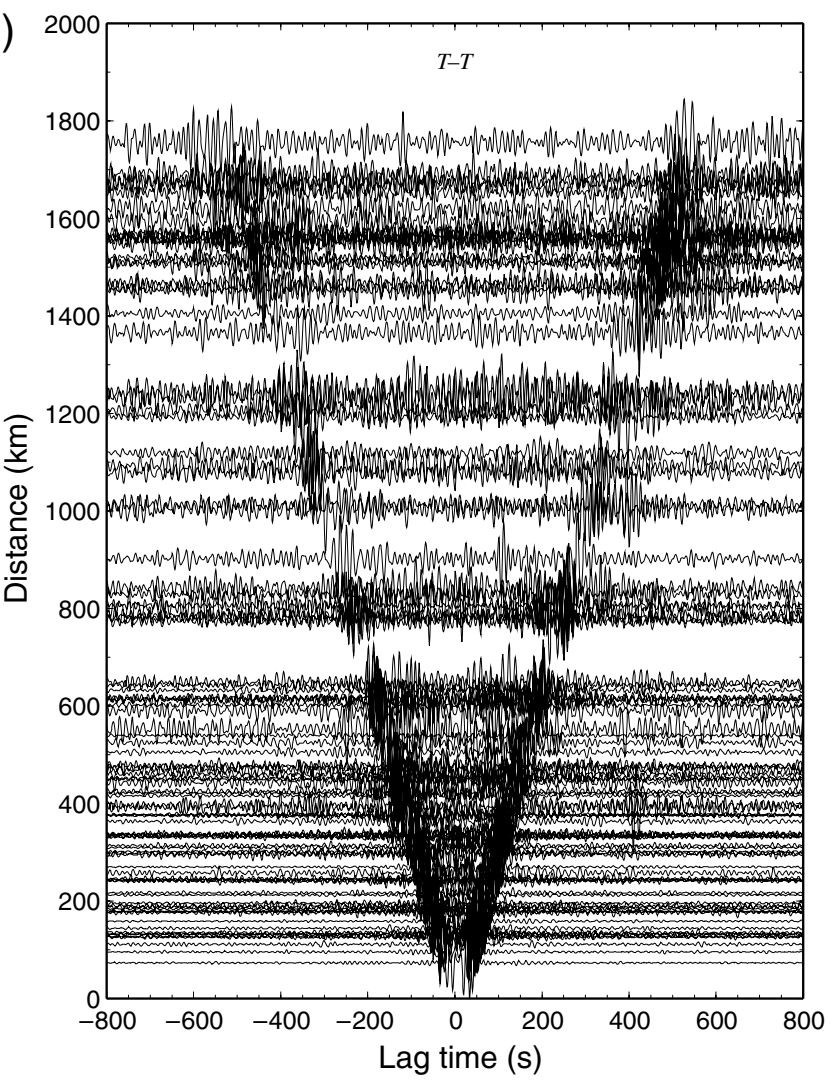

Figure 2. The 10-100 s band-pass filtered cross-correlation record section centered at station ZEKU with (a) vertical-vertical ( $Z-Z)$ cross correlations and (b) transverse-transverse $(T-T)$ cross correlations.

structures from Rayleigh- and Love-wave group velocities and discuss their geologic and tectonic implications.

\section{Data Selection and Processing}

In this study, we collected continuous three-component broadband seismic data recorded at 81 regional stations from the China Earthquake Networks Center between January 2008 and September 2009 and 32 temporary stations from June 2008 to July 2010. We followed the same ambient noise cross-correlation processing procedure as described in our previous studies (Li et al., 2009; Li, Bernardi, and Michelini, 2010; Li, Su, et al., 2010; Li et al., 2012). The data were first windowed into one-hour-long time series, after removing trend, mean value, and instrument response. The north-south and east-west components were then rotated to the radial and transverse components for each station pair by setting the first station as the event and the second station as the receiver before the cross correlations are calculated and stacked. Next, each stacked cross correlation was cut into positive and negative lags, and the two correlation lags were added together to produce the final cross-correlation function.

Figure 2 shows record sections of cross correlations between station ZEKU and other stations for the Rayleigh wave ( $Z-Z$; Fig. 2a) and the Love wave ( $T-T$; Fig. 2b), respectively. As seen in Figure 2, clear signals simultaneously emerge at both positive and negative correlation lags for Rayleigh and Love waves, and Rayleigh waves generally display a higher signal-to-noise ratio than Love waves. Then the group velocity dispersion measurement was performed based on the multiple-filter technique with phase-matched processing (Dziewonski et al., 1969; Herrmann, 1973). The waveforms were first band-pass filtered with the narrowband Gaussian filter operator $\exp \left[-\alpha\left(\omega-\omega_{0}\right)^{2} / \omega_{0}^{2}\right]$, in which $\omega_{0}$ is the central frequency of the desired period and $\alpha$ is a tunable parameter to balance the resolutions in the frequency and time domains and is usually distance dependent. After that, a phasematched filter was then constructed and performed for the signal to isolate the fundamental mode. We visually checked each dispersion measurement to make sure that only the reliable dispersion curves were selected for our inversion. In this study, we obtained more than 3200 group velocity dispersion curves for Rayleigh waves and about 2000 curves for Love waves.

Figure 3 shows the number of group velocity dispersion measurements for Rayleigh and Love waves at different periods. In this article, only station pairs with the interstation distances larger than three wavelengths of the waves of interest are selected for our inversion. Because of higher noise levels on the horizontal components, fewer interstation paths of Love waves are selected from the cross correlation of the $T-T$ component in comparison with Rayleigh waves from that of $Z-Z$ component. For the Rayleigh-wave tomography, 


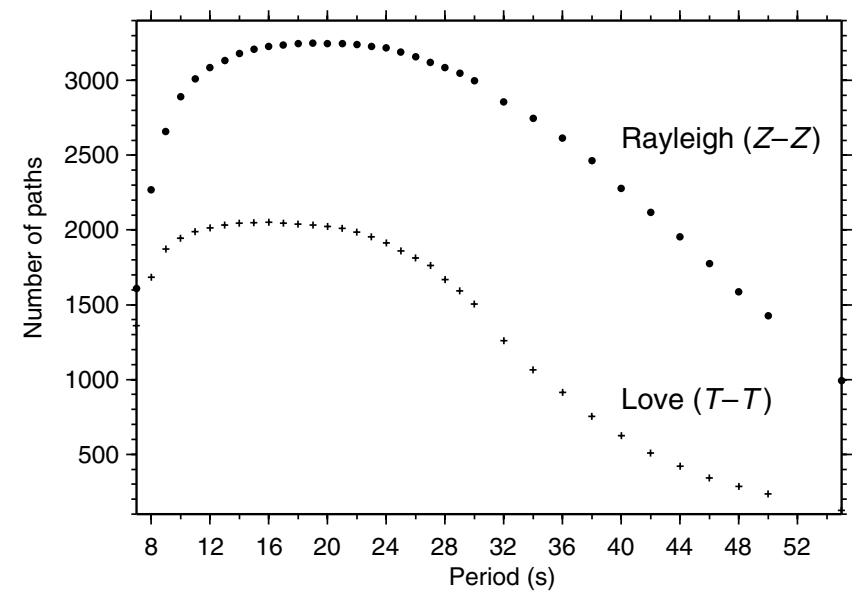

Figure 3. Number of group velocity dispersion measurements at different periods.

the longest period can extend to about $50 \mathrm{~s}$; however, for the Love-wave tomography at periods longer than $40 \mathrm{~s}$, the station coverage becomes poor for most of the study area except for the southern Qilian orogen.

\section{Group Velocity Tomography}

The dispersion measurements from more than 3200 paths were used to invert for group velocity maps at periods from 10 to $50 \mathrm{~s}$ for Rayleigh and Love waves. The study area was divided into a $0.4^{\circ} \times 0.4^{\circ}$ grid, and the Occam's inversion scheme, which seeks a smooth model that fits the observations (Constable et al., 1987), was adopted for inversion (Constable et al., 1987; DeGroot-Hedlin and Constable, 1990). Before inversion, checkerboard tests were conducted to evaluate lateral resolution with the Occam's inversion technique. Figure 4a shows an input checkerboard velocity model. The size of alternative low- and high-velocity cells is $0.4^{\circ}$. Alternating positive and negative $\pm 5 \%$ velocity perturbations are assigned to each cell, with average velocity of $3.0 \mathrm{~km} / \mathrm{s}$. Synthetic group velocity data were calculated according to the actual paths at the $30 \mathrm{~s}$ period, and then random errors with a standard deviation of $0.05 \mathrm{~km} / \mathrm{s}$ were added to each path. Figure $4 \mathrm{~b}$ and $\mathrm{c}$ shows the ray-path density at the $30 \mathrm{~s}$ period for Rayleigh and Love waves, respectively. Generally, the coverage is good for the northeastern and southern parts (the Qilian orogen, east KLF, and the south of the Qaidam basin), but in the western part of the study region, the path coverage (and hence resolution) is poor due to few available stations. The checkerboard test results are given in Figure 4d for Rayleigh wave and Figure 4e for Love wave. The reconstructed velocity models are basically correct in most of the study area. The resolving power is generally good in the northeastern and southeastern parts of the study area, but it becomes worse beneath the Qaidam basin where the path coverage is sparse. The lateral resolution is estimated to be $\sim 0.8^{\circ}$ for both Rayleigh and Love waves in the eastern part of the study area and $1.2^{\circ}$ for the Rayleigh wave beneath the Qaidam basin. Surface wave speeds are known to exhibit a frequency-dependent sensitivity to the Earth's structure. In general, the longer the period, the deeper the surface-wave energy penetrates. Because our previous study (Li et al., 2012) gave the radial sensitivity kernels for Rayleigh and Love waves and showed that Rayleigh waves sample down to depths approximately one-third of their wavelength and Love waves are more affected by shallow structures, we do not elaborate here.

The Rayleigh-wave group velocity images at 10,30, and $50 \mathrm{~s}$ are presented in Figure 5. At the short-period range $(\leq 20$ s) Rayleigh-wave group velocities are most sensitive to shear velocities in the upper crust. In the $10 \mathrm{~s}$ period map (Fig. 5a), the prominent low group velocities are clearly observed beneath the Qaidam basin. The surrounding mountain areas show overall higher velocities than the basin at this period. We note a small patch of high velocity in the northern part of the Qilian orogen. At the $30 \mathrm{~s}$ period (Fig. 5b), the Qaidam basin is still featured with very low velocity; meanwhile, a very low group velocity anomaly also occurs in the Songpan-Ganzi terrane. We also note that the small patch of high velocity in the northernmost Qilian orogen still exists. In the $50 \mathrm{~s}$ map (Fig. 5c), the group velocity distribution is different from those at short-to-intermediate periods, the lowest velocities are observed beneath the Songpan-Ganzi terrane rather than the Qaidam basin. The Love-wave maps at 10 and 30 s (Fig. 6) exhibit similar features to the Rayleigh-wave maps. In the $10 \mathrm{~s}$ Love-wave map (Fig. 6a), the low velocity also appears beneath the Qaidam basin, and a small patch of high velocity is observed beneath the northernmost Qilian orogen. In the $30 \mathrm{~s}$ map (Fig. 6b), the Qaidam basin and the Songpan-Ganzi terrane still show low velocities. The strong difference in group velocities among the different subregions reveals strong lateral variations in the crust in the northeast Tibetan plateau.

\section{Shear-Wave Velocity Structure}

As it is well known that surface waves at different periods are sensitive to the shear-wave velocity structure over different depth ranges, so they can provide useful information to constrain the shear-wave velocity structure and valuable insights into the lateral variation of shear-wave velocities in different depths. We use the pure-path Rayleighand Love-wave dispersion curves for each grid node to carry out inversion for the shear-wave velocity structure with a program developed by Herrmann and Ammon (2004). The shear-wave velocity in each layer with fixed thickness is taken as the inversion parameter, and $P$-wave velocity and density are calculated from shear-wave velocity with empirical formulas. The shear-wave velocity and Moho depth in the initial models are referred to the deep seismic sounding profiles (Xu et al., 2002; Zhao et al., 2004; S. Li et al., 2006), tomography results (Huang et al., 2003; Wang et al., 2003, 2007; Maceira et al., 2005), and receiver functions (Pan and Niu, 2011; (E) Fig. S1, available in the electronic 
(a)

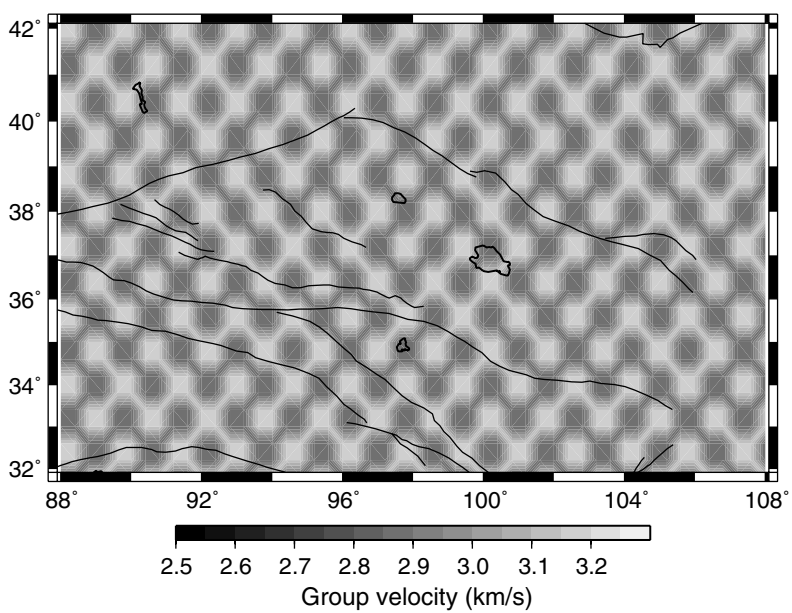

(c)

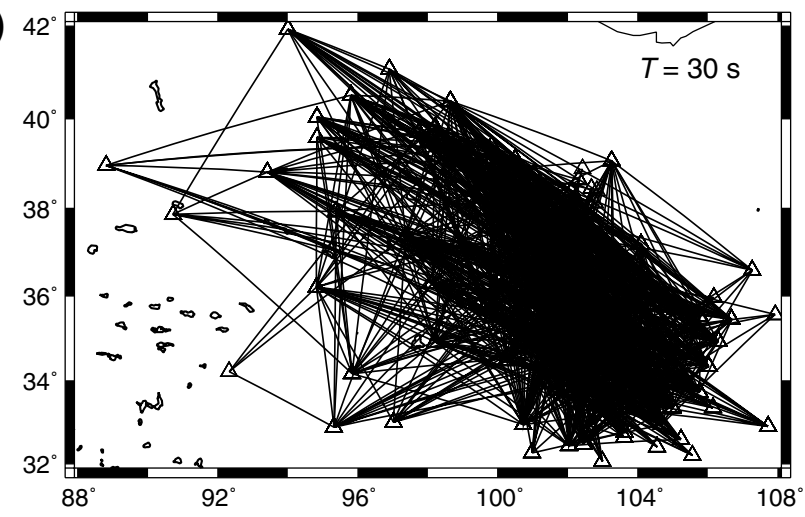

(b)

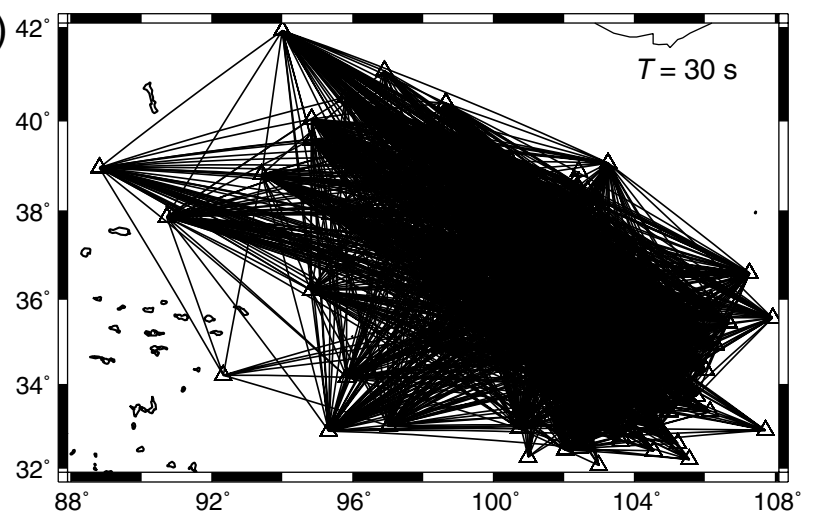

(d)

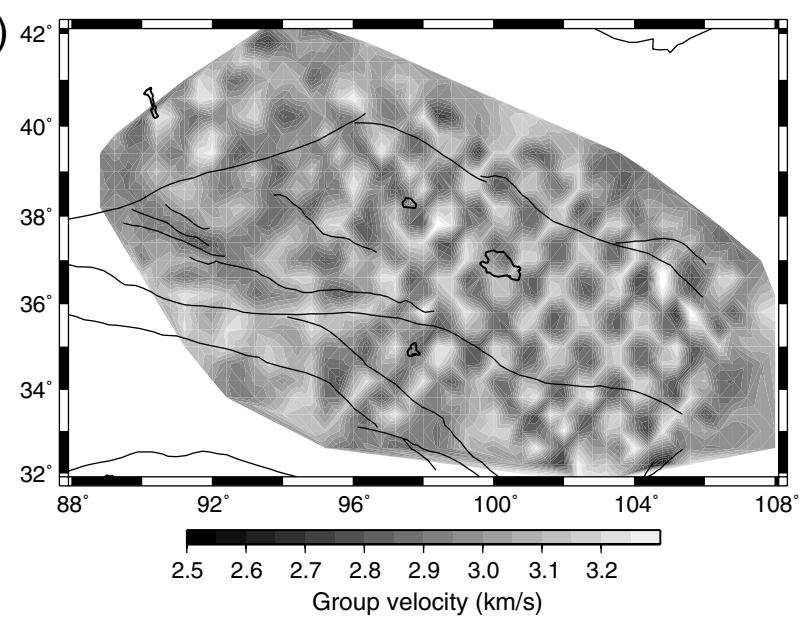

(e)

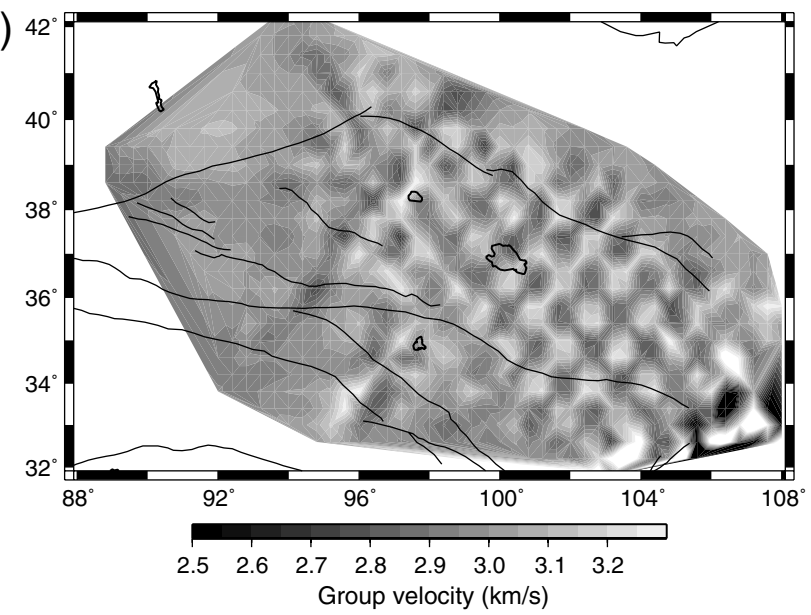

Figure 4. Checkerboard resolution tests with a grid spacing of $0.8^{\circ}$. (a) Theoretical model for $T=30 \mathrm{~s}$ with disturbing velocities $3.0 \pm 0.15 \mathrm{~km} / \mathrm{s}$. Path coverage at periods of $30 \mathrm{~s}$ for (b) Rayleigh wave and (c) Love wave. Inversion results for (d) Rayleigh wave and (e) Love wave.

supplement to this article). Because surface waves have poor ability to resolve the velocity discontinuity and the trade-off between the shear-wave velocity and Moho depth, we used 10 different initial models by adjusting the shear-wave velocity (E) Fig. S4, available in the electronic supplement), layer thickness, and Moho depth, then the inversion was repeated
10 times, and the final shear-wave velocity structure was averaged from the 10 inversion solutions.

In our inversion, we adopted an isotropic model to simultaneously fit both Raleigh- and Love-dispersion curves, however, we noticed that for some particular cells showing an LVZ in its mid-to-lower crust, it is hard to fit both 

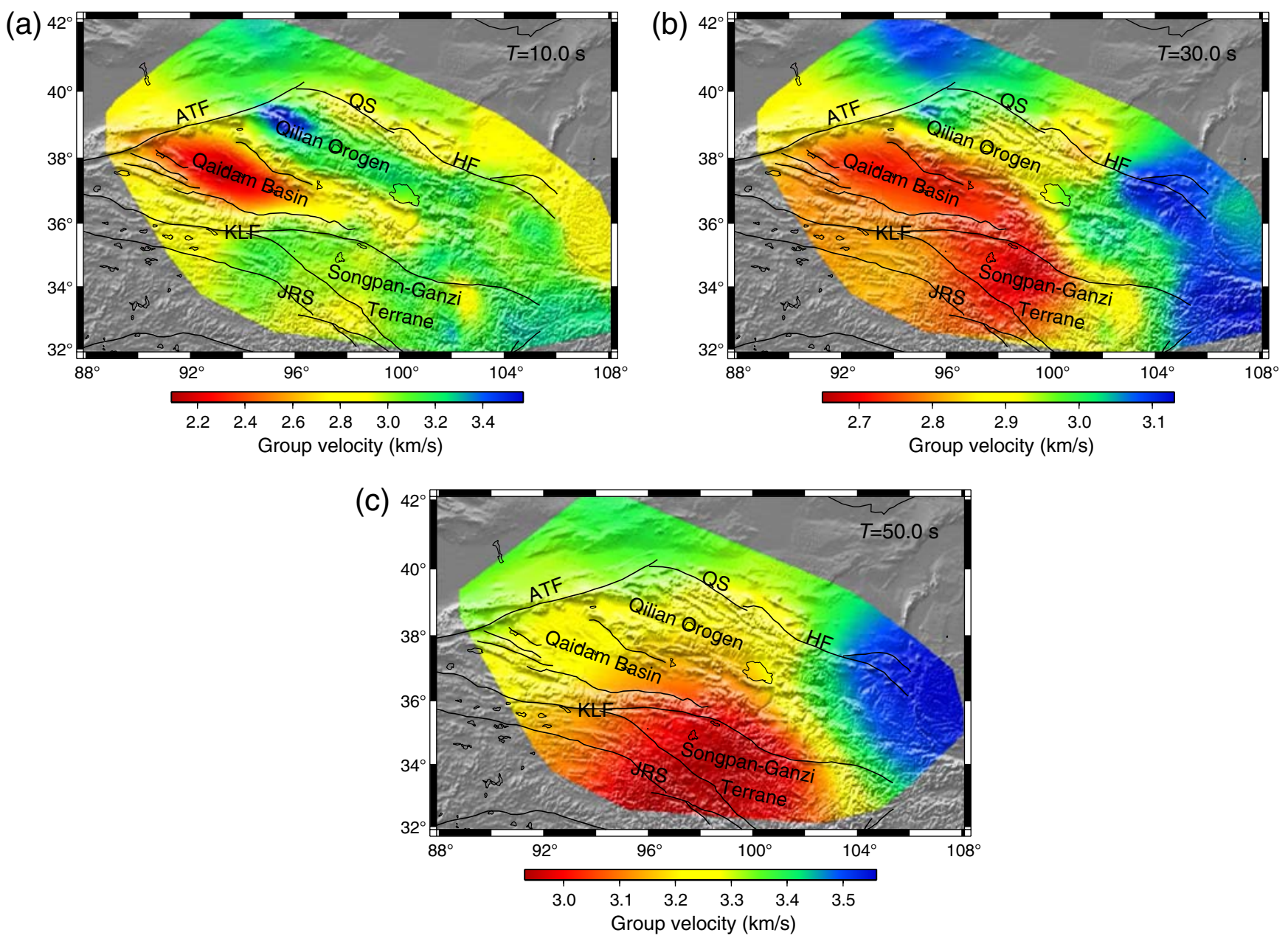

Figure 5. Estimated Rayleigh-wave group velocity maps at (a) $10 \mathrm{~s}$, (b) $30 \mathrm{~s}$, and (c) $50 \mathrm{~s}$. Period is indicated in the upper right corner of each map. The color version of this figure is available only in the electronic edition.

Rayleigh- and Love-wave dispersion curves, which could relate to the radial anisotropy. Therefore, the obtained $S$-wave velocity structure in our inversion is somehow the average between $V_{S \mathrm{v}}$ and $V_{S \mathrm{~h}}$. An example of pure path dispersion curves and their corresponding 1D shear-wave velocity models is presented in Figure 7. The location of the grid $\left(104.8^{\circ} \mathrm{E}, 35^{\circ} \mathrm{N}\right)$ is identified with a star in Figure $1 \mathrm{~b}$. The synthetic dispersion curves for both the Rayleigh and Love waves generally resemble the observed ones well.

The final $S$-wave velocity structures at depths of 10, 20, 30 , and $40 \mathrm{~km}$ are shown in Figure 8 . The $S$-wave velocity structure shows significant differences with depth in the study area. Pronounced low shear-wave velocities appear in the Songpan-Ganzi terrane and in the vicinity of the KLF, from the mid-to-lower crust down to at least $40 \mathrm{~km}$ (Fig. 8). At $10 \mathrm{~km}$ depth, the Qaidam basin is characterized by a low $S$-wave velocity, and a small patch of very-high-velocity anomaly is observed in the northernmost Qilian orogen (Fig. 8a). Low-velocity anomalies at shallow depth beneath the Qaidam basin could be due to thick sedimentary layers because the Qaidam basin has been in a stable sedimentary environment since Cenozoic time (Chen et al., 1999; Métivier et al., 1999). At depths of $20 \mathrm{~km}$, the velocity distribution is quite different from velocities at $10 \mathrm{~km}$. The high $S$-wave velocity appears beneath the Qaidam basin. The upper crust of the Songpan-Ganzi terrane and KLF is characterized by the lowest velocity. Figure $8 \mathrm{c}$ shows that at the depth of $30 \mathrm{~km}$, the Qaidam basin is featured with a relatively higher velocity and the Songpan-Ganzi terrane with a lower velocity. We note that relatively lower velocities are observed beneath the north Qilian orogen instead of high velocities at shallow depth (Fig. 8c). The shear-wave velocity map at $40 \mathrm{~km}$ depth (Fig. 8d) shows a similar velocity distribution as at the depth of $30 \mathrm{~km}$ except that the LVZ beneath the north Qilian orogen is more obvious and becomes larger than that at depth of $30 \mathrm{~km}$. This shear-wave velocity model offers new insights into the subsurface structures beneath the northeast Tibetan plateau, and its implications to the deformation and rise of the Tibetan plateau are discussed in the Discussion section.

Figure 9 presents shear-wave velocity structure along two vertical profiles from the surface down to $70 \mathrm{~km}$ depth. In the AA' profile (Fig. 9a) through the Songpan-Ganzi terrane to the southern Qilian orogen, an evident mid-tolower crustal LVZ is present only beneath the Songpan- 
(a)

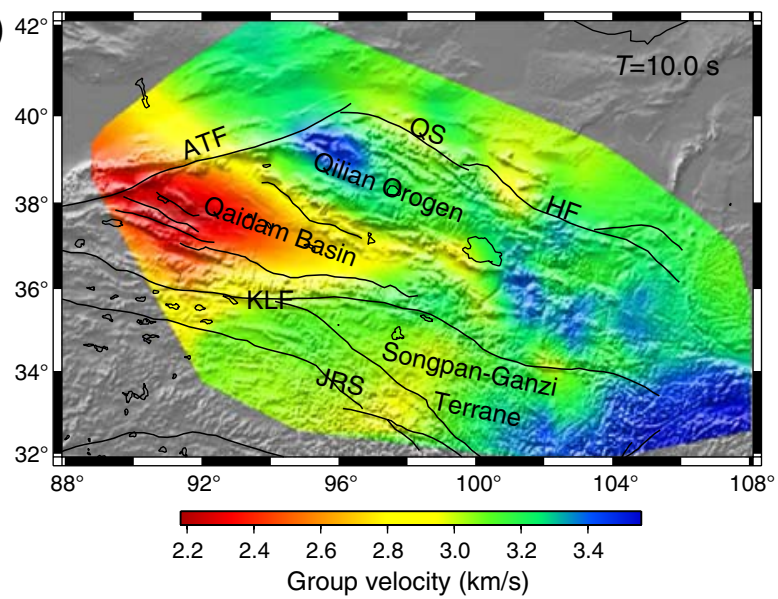

(b)

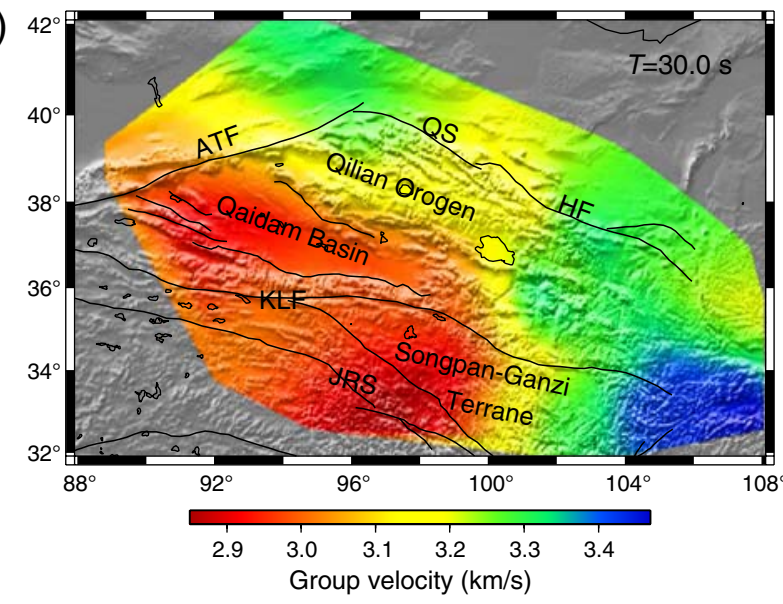

Figure 6. Estimated Love-wave group velocity maps at (a) $10 \mathrm{~s}$ and (b) $30 \mathrm{~s}$. Period is indicated in the upper right corner of each map. The color version of this figure is available only in the electronic edition.

Ganzi terrane but not beneath the southern Qilian orogen. In the $\mathrm{BB}^{\prime}$ profile crossing the Songpan-Ganzi terrane and the northern Qilian orogen (Fig. 9b), an LVZ in the mid-to-lower crust exists beneath the Songpan-Ganzi terrane and the northern Qilian orogen.

\section{Discussion}

Generally speaking, our group velocity maps show high correlations with the major tectonic units in the study region. At the same time, both our group velocity maps (Figs. 5 and 6) and shear-wave velocity maps (Fig. 8) reveal significant anomalies within our study area.

Low velocities are clearly observed in the Qaidam basin. However, high velocities are associated with the mountainous areas at short periods (Figs. 5a and 6a) because most mountain regions are mainly dominated by metamorphic rocks (compared with sediment-filled basin). It is well known that seismic velocities of sediments are much lower than those of metamorphic rocks. At 30 s period (Figs. 5b and 6b), the Qaidam basin is still featured with low velocity and shows the influence of (a)
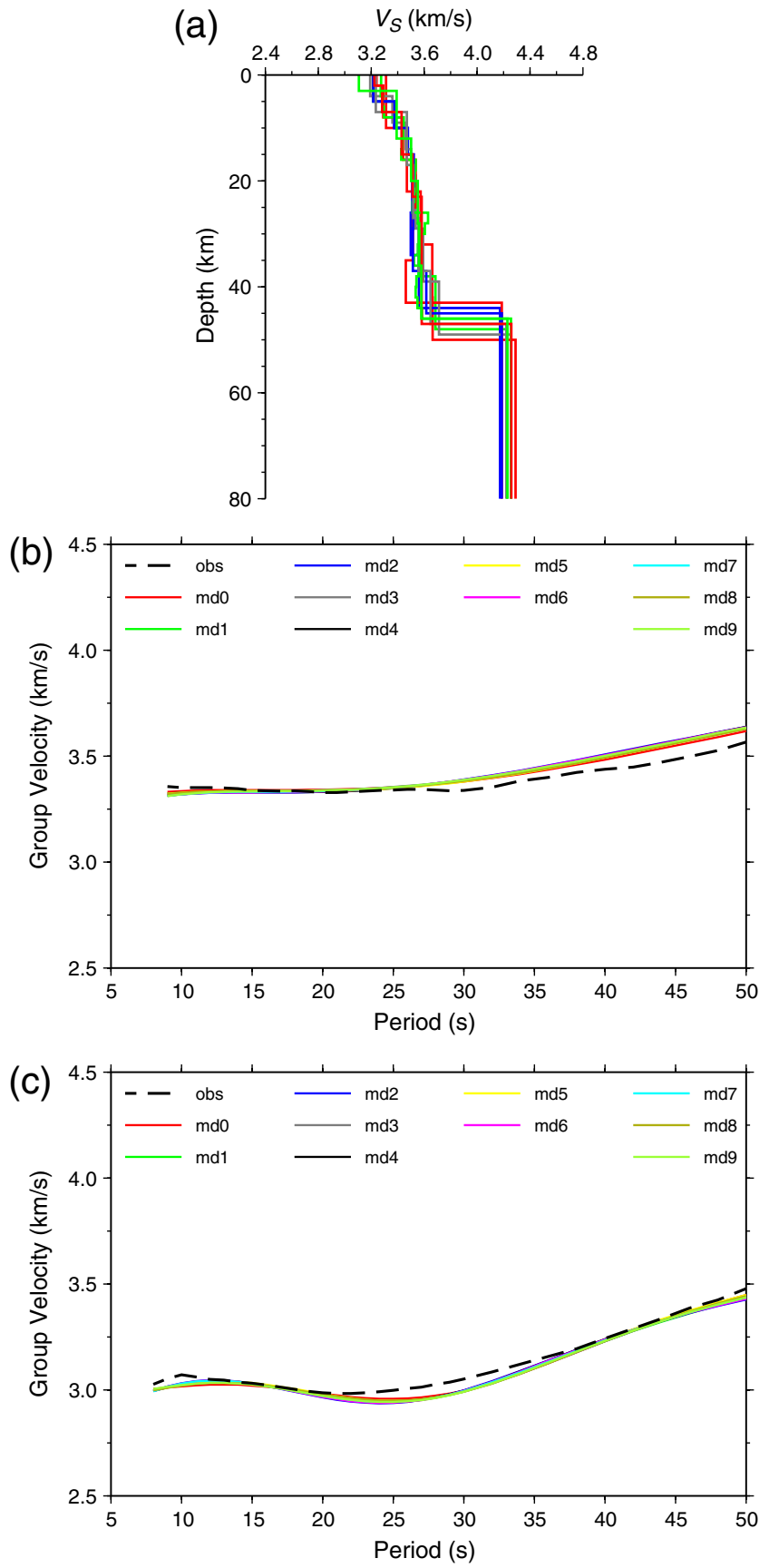

Figure 7. Example of local dispersion curve and the corresponding 1D shear-wave velocity models at the location marked in Figure $1 \mathrm{~b}$ as the star. (a) The 10 inverted 1D velocity models, (b) the observed (dashed line) and synthetic Love-wave dispersion curves from 10 models, and (c) the observed (dashed line) and synthetic Rayleigh-wave dispersion curves. The color version of this figure is available only in the electronic edition.

sedimentary layers. With the increase of the period, surfacewave energy penetrates the deeper structure of the Earth, so the surface-wave velocities are mainly influenced by the thickness of the crust, as well as the shear velocities in the lower crust and uppermost mantle. For the Love-wave velocity map at $30 \mathrm{~s}$, due to more than $8 \mathrm{~km}$ sedimentary cover on average beneath the Qaidam basin, the imprint of the sedimentary 
(a)

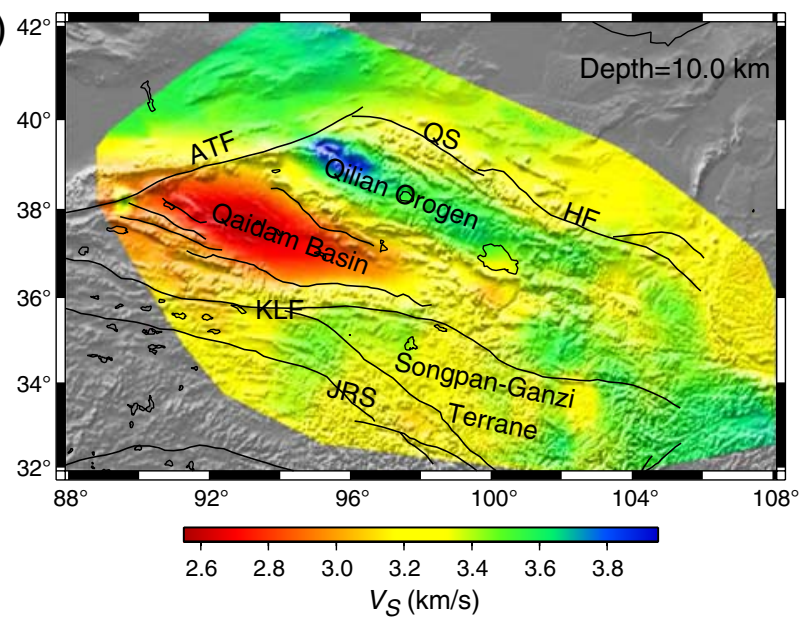

(c)

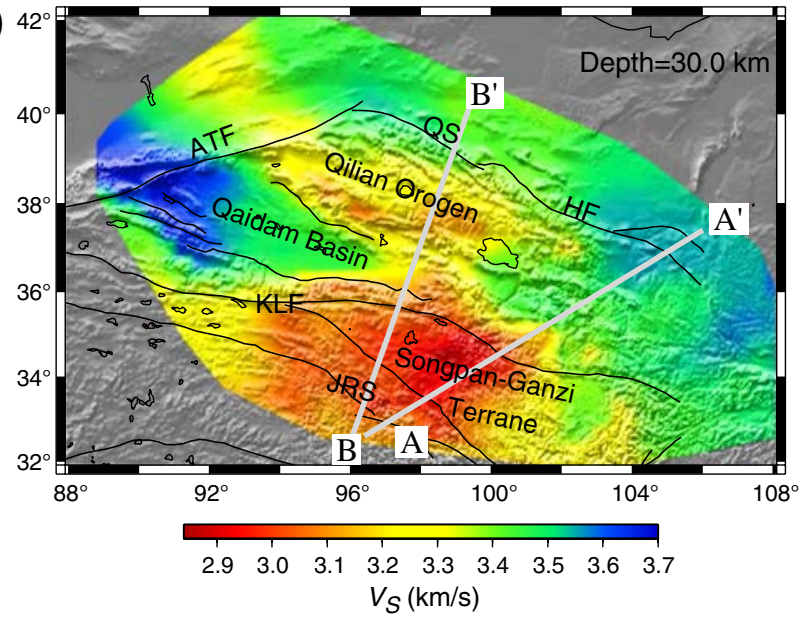

(b)

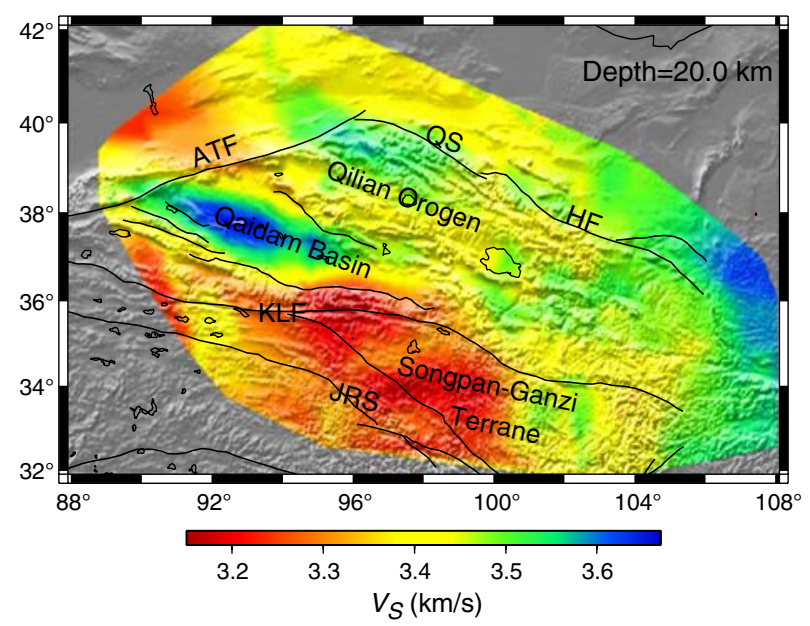

(d)

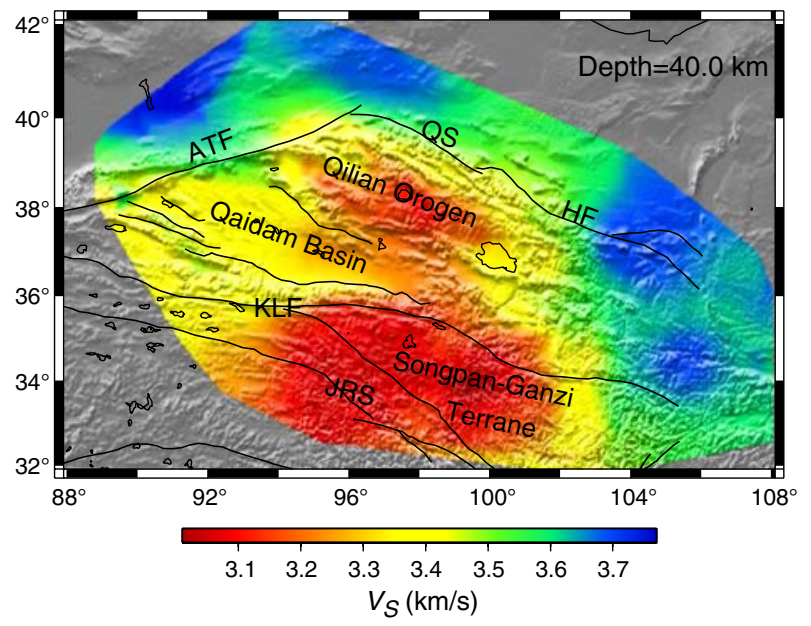

Figure 8. Shear-wave velocity maps at depth (a) $10 \mathrm{~km}$, (b) $20 \mathrm{~km}$, (c) $30 \mathrm{~km}$, and (d) $40 \mathrm{~km}$. Depth is indicated in the upper right corner of each panel. The dark lines show major tectonic features. Lines in (c) delineate the locations of the vertical cross sections shown in Figure 9. The color version of this figure is available only in the electronic edition.

layers still exists; therefore, the velocity map at $30 \mathrm{~s}$ is influenced not only by the lower crust, but also by the thick sediments. At the $30 \mathrm{~s}$ period, the Songpan-Ganzi terrane shows low velocity due to its thicker crust compared with the basin areas. Rayleigh-wave velocity maps at greater periods $(50 \mathrm{~s}$, Fig. 5c) show an inverse correlation with the crustal thickness variation. The Qaidam basin is overall associated with high velocity due to relatively thin crustal thickness in comparison with the mountain areas.

The shear-wave velocity structures derived from both Rayleigh- and Love-wave dispersion curves show that the Songpan-Ganzi terrane is featured with a prominent LVZ in its mid-to-lower crust $(\sim 20-40 \mathrm{~km})$, which is consistent with the $P$-velocity model (C. Li et al., 2006) in this area. Meanwhile, as seen in Figures 8 and 9, it is very striking that the northern Qilian orogen associated with a relatively higher topography also features an LVZ in the middle crust, but the LVZ has not been observed beneath the southern Qilian orogen.

What causes such a low-velocity anomaly and the distribution of the mid-to-lower crustal LVZ beneath the Tibetan plateau are the important questions that need to be discussed. If the lower-crustal velocity were laterally more uniform, this would accentuate the proposed Moho topography (Q. Zhang et al., 2011). The mid-to-lower LVZ beneath the SongpanGanzi terrane is similar to the LVZs observed beneath other parts of the plateau, such as the eastern, central, and southern Tibetan plateau. Geophysical studies using different methods also found high-electrical conductivity, high-temperature, partial melting, low-velocity, and low-strength zones in the mid-to-lower crust beneath the plateau (e.g., Clark et al., 2005; Royden et al., 2008; Yao et al., 2008; Guo et al., 2009; Li et al., 2009; Bai et al., 2010; Yang et al., 2012). The crustal flow model suggested that the weak mid-to-lower crustal materials beneath the Tibetan plateau probably contributed to the elevated topography and crustal thickening of the Tibetan plateau (Clark and Royden, 2000; Royden et al., 2008). In their models, they proposed when the crust of adjacent regions is cold and strong, then the weak mid-to-lower crust beneath the plateau could be difficult to flow into adjacent regions, and therefore a narrow and steep plateau margin has been built up. If the crust of adjacent regions is also 
(a)

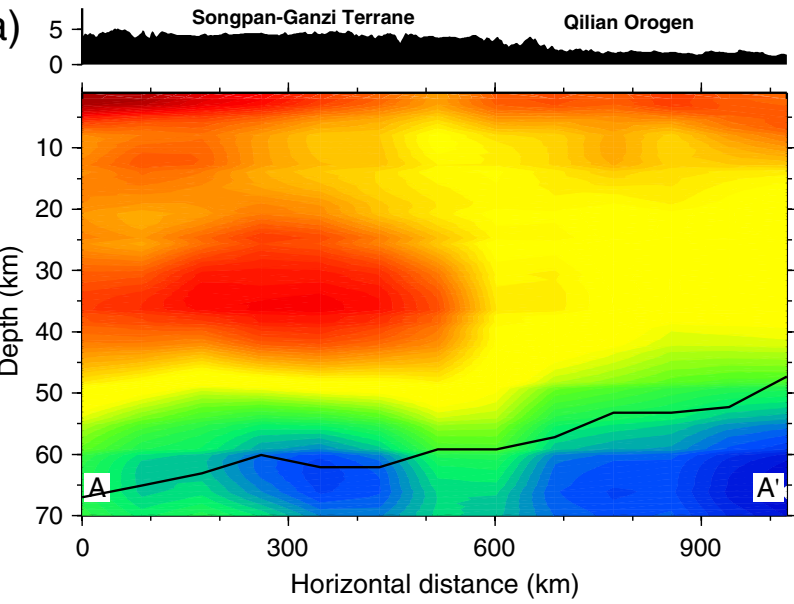

(b)

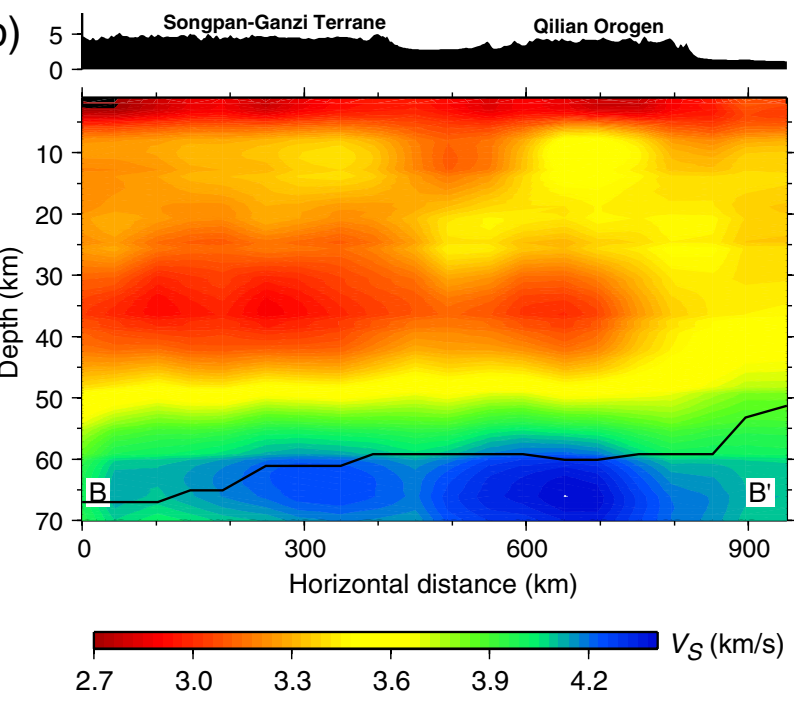

Figure 9. Vertical cross sections of $S$-wave velocity along the profiles $\mathrm{AA}^{\prime}$ and $\mathrm{BB}^{\prime}$ shown in Figure $8 \mathrm{c}$. The solid curves are the Moho depth. The color version of this figure is available only in the electronic edition.

weak, then the mid-to-lower crust could escape to regions where crust is weak, thus resulting in a broad and gentle plateau margin with long wavelength and low topographic gradient. Based on their model, in the northeastern plateau margin with a gentle topography gradient, the weak mid-tolower crustal materials could escape through the SongpanGanzi terrane toward the southwestern Ordos platform.

Our results show that a mid-to-lower crustal LVZ has been observed beneath the northern Qilian orogen, with the highest topography and a thickened crust ( $60 \mathrm{~km}$; Yue et al., 2012) compared to its surrounding regions. However, it has not been found beneath the southern Qilian orogen. Because our data have poor resolution in the Qaidam basin, it is hard to evaluate whether the LVZ exists beneath the Qaidam basin and the LVZ beneath the Songpan-Ganzi terrane flows through the Qaidam basin to the northern Qilian orogen. However, our observations in the southern Qilian orogen are probably inconsistent with the simple crustal flow model, in which the eastward moving crust of the central plateau is diverted northeast and southeast around the Sichuan basin. Therefore, it would support a gentle long-wavelength topographic gradient along the northeastern edge of the Tibetan plateau toward the Ordos platform (Clark et al., 2005; Royden et al., 2008). The lateral distribution of the LVZ beneath the northern Qilian orogen shows a very good correlation with the area of thickened crust and highest topography. As a result of the continent-continent collision, the main part of the Tibetan plateau was uplifted and has a very thick crust, and the mid-crustal LVZ is widely distributed in the main plateau. Therefore, we infer that the midto-lower crustal LVZ beneath the northwestern Qilian orogen may be attributed to the crustal thickening and surface uplift responding to the ongoing collision of the plateau, which is similar to that of the main part of the Tibetan plateau; however, at this point, it could be difficult to use our results to support the crustal flow mode.

\section{Conclusion}

In this study, we obtained group velocity maps of Rayleigh and Love waves in the northeast Tibetan plateau using broadband seismic data recorded by temporary broadband seismic arrays and the regional seismic networks. Crosscorrelation functions are computed in one-hour segments, and group velocity dispersion curves are determined using the multiple-filter analysis technique. The large variation of velocity structure indicates strong heterogeneities and structure complexities in the study area. Prominent low-velocity layers have been found in the mid-to-lower crust beneath the Songpan-Ganze terrane and the northern Qilian orogen. The LVZ beneath the northern Qilian orogen may be attributed to the crustal thickening and surface uplift, which is responding to the ongoing collision. From this study, there is no clear evidence of the low-velocity mid-to-lower crust beneath the southern Qilian orogen as the crustal flow model predicts.

\section{Data and Resources}

The continuous seismic data used in this study were from the northeastern Tibet seismic (NETS) experiment (Shen et al., 2008) and the China Earthquake Networks Center. The inversion program for the shear-wave velocity structure can be found at http://www.eas.slu.edu/People/ RBHerrmann/CPS330.html (last accessed September 2012).

\section{Acknowledgments}

We are grateful to the China Earthquake Networks Center for providing the broadband seismic data. We also thank Xinlei Ma, who is working in National Library of China, and Xin Wang, who is working in China Geological Library, for providing most of the references. All of the figures were rendered using Generic Mapping Tools (Wessel and Smith, 1998). This research was supported by the National Science Foundation of China (Grant Numbers 41174050 and 40804007) and the Fundamental Research Funds for the Central Universities, as well as the United States National Science Foundation (Grant Number 0738779). 


\section{References}

Arnaud, N. O., Ph. Vidal, P. Tapponnier, Ph. Matte, and W. Deng (1992). The high $\mathrm{K}_{2} \mathrm{O}$ volcanism of northwestern Tibet: Geochemistry and tectonic implications, Earth Planet. Sci. Lett. 111, 351-367.

Bai, D., M. J. Unsworth, M. A. Meju, X. Ma, J. Teng, X. Kong, Y. Sun, J. Sun, L. Wang, C. Jiang, C. Zhao, P. Xiao, and M. Liu (2010). Crustal deformation of the eastern Tibetan plateau revealed by magnetotelluric imaging, Nature Geosci. 3, 358-362.

Bendick, R., and L. Flesch (2007). Reconciling lithospheric deformation and lower crustal flow beneath central Tibet, Geology 35, 895-898, doi: 10.1130/G23714A.1.

Brown, L. D., W. Zhao, K. D. Nelson, M. Hauck, D. Alsdorf, A. Ross, M. Cogan, M. Clark, X. Liu, and J. Che (1996). Bright spots, structure, and magmatism in southern Tibet from INDEPTH seismic reflection profiling, Science 274, 1688-1690.

Chen, W., C. Chen, and J. L. Nabelek (1999). Present-day deformation of the Qaidam basin with implications for intra-continental tectonics, Tectonophysics 305, 165-181.

Chung, S., M. Chu, Y. Zhang, Y. Xie, C. Lo, T. Lee, C. Lan, X. Li, Q. Zhang, and Y. Wang (2005). Tibetan tectonic evolution inferred from spatial and temporal variations in post-collisional Magmatism, Earth Sci. Rev. 68, 73-196.

Clark, M., and L. Royden (2000). Topographic ooze: Building the eastern margin of Tibet by lower crustal flow, Geology 28, 703-706.

Clark, M., J. Bush, and L. Royden (2005). Dynamic topography produced by lower crustal flow against rheological strength heterogeneities bordering the Tibetan plateau, Geophys. J. Int. 162, 575-590.

Constable, S., R. Parker, and C. Constable (1987). Occam's inversion: A practical algorithm for generating smooth models from electromagnetic sounding data, Geophysics 52, 289-300.

Dai, J., C. Wang, R. Hebert, Y. Li, H. Zhong, R. Guillaume, R. Bezard, and Y. Wei (2011). Late Devonian OIB alkaline gabbro in the Yarlung Zangbo suture zone: Remnants of the Paleo-Tethys? Gondwana Research, Special Section: The South and East Facades of Sundaland 19, no. 1, 232-243, doi: 10.1016/j.gr.2010.05.015.

DeGroot-Hedlin, C., and S. Constable (1990). Occam's inversion to generate smooth, two dimensional models from magnetotelluric data, Geophysics 55, no. 12, 1613-1624.

Deng, W. (1997). Cenozoic volcanism and lithosphere tectonic evolution in the northern Tibetan plateau, China, in Igneous Petrology, Z. Li, J. Qi, and Z. Zhang (Editors), Vol. 15, 30th International Geological Congress, Utrecht, The Netherlands, Tokyo, Japan, 3-12.

Dziewonski, A., S. Block, and M. Landisman (1969). A technique for the analysis of transient seismic signals, Bull. Seismol. Soc. Am. 59, 427-444.

Guo, Z., X. Gao, H. Yao, J. Li, and W. Wang (2009). Midcrustal low-velocity layer beneath the central Himalaya and southern Tibet revealed by ambient noise array tomography, Geochem. Geophys. Geosyst. 10, Q05007, doi: 10.1029/2009GC002458.

Herrmann, R. B. (1973). Some aspects of band-pass filtering of surface waves, Bull. Seismol. Soc. Am. 63, no. 2, 663-671.

Herrmann, R. B., and C. J. Ammon (2004). Surface waves, receiver functions and crustal structure, Computer Programs in Seismology, Version 3.30, Saint Louis University, Missouri.

Huang, W., J. Ni, F. Tilmann, D. Nelson, J. Guo, W. Zhao, J. Mechie, R. Kind, J. Saul, R. Rapine, and T. Hearn (2000). Seismic polarization anisotropy beneath the central Tibet plateau, J. Geophys. Res. 105, 27979-27989.

Huang, Z., W. Su, Y. Peng, Y. Zheng, and H. Li (2003). Rayleigh wave tomography of China and adjacent regions, J. Geophys. Res. 108, no. B2, 2073, doi: 10.1029/2001JB001696.

Karplus, M. S., S. L. Klemperer, J. F. Lawrence, W. Zhao, J. Mechie, F. Tilmann, E. Sandvol, and J. Ni (2013). Ambient-noise tomography of north Tibet limits geological terrane signature to upper-middle crust, Geophys. Res. Lett. 40, no. 5, 808-813, doi: 10.1002/grl.50202.

Karplus, M. S., W. Zhao, S. L. Klemperer, Z. Wu, J. Mechie, D. Shi, L. D. Brown, and C. Chen (2011). Injection of Tibetan crust beneath the south Qaidam basin: Evidence from INDEPTH IV wide-angle seismic data, J. Geophys. Res. 116, B07301, doi: 10.1029/2010JB007911.

Kind, R., J. Ni, W. Zhao, J. Wu, X. Yuan, L. Zhao, E. Sandvol, C. Reese, J. Nabelek, and T. Hearn (1996). Evidence from earthquake data for a partially molten crustal layer in southern Tibet, Science 274, 1692-1694.

Kind, R., X. Yuan, J. Saul, D. Nelson, S. V. Sobolev, J. Mechie, W. Zhao, G. Kosarev, J. Ni, U. Achauer, and M. Jiang (2002). Seismic images of crust and upper mantle beneath Tibet: Evidence for Eurasian plate subduction, Science 298, no. 5596, 1219-1221.

Li, C., R. van der Hilst, and M. Toksöz (2006). Constraining $P$-wave velocity variations in the upper mantle beneath southeast Asia, Phys. Earth Planet. In. 154, no. 2, 180-195.

Li, H., F. Bernardi, and A. Michelini (2010). Surface wave dispersion measurements from ambient seismic noise analysis in Italy, Geophys. J. Int. 180, no. 3, 1242-1252, doi: 10.1111/j.1365-246X.2009.04476.x.

Li, H., S. Li, X. Song, M. Gong, X. Li, and J. Jia (2012). Crustal and uppermost mantle velocity structure beneath northwestern China from seismic ambient noise tomography, Geophys. J. Int. 188, no. 1, 131-143, doi: 10.1111/j.1365-246X.2011.05205.x.

Li, H., W. Su, C. Wang, and Z. Huang (2009). Ambient noise Rayleigh wave tomography in western Sichuan and eastern Tibet, Earth Planet. Sci. Lett. 282, nos. 1/4, 201-211.

Li, H., W. Su, C. Wang, Z. Huang, and Z. Lv (2010). Ambient noise Love wave tomography in the eastern margin of the Tibetan plateau, Tectonophysics 491, nos. 1/4, 194-204, doi: 10.1016/j.tecto.2009.12.018.

Li, S., D. Walter, and J. Fan (2006). Crustal structure of mainland China from deep seismic sounding data, Tectonophysics 420, no. 12, 239-252.

Maceira, M., S. R. Taylor, C. J. Ammon, X. Yang, and A. A. Velasco (2005). High-resolution Rayleigh wave slowness tomography of central Asia, J. Geophys. Res. 110, B06304, doi: 10.1029/2004JB003429.

Métivier, F., Y. Gaudemer, P. Tapponnier, and M. Klein (1999). Mass accumulation rates in Asia during the Cenozoic, Geophys. J. Int. 137, no. 2 , 280-318.

Molnar, P., and P. Tapponnier (1975). Cenozoic tectonics of Asia: Effects of a continental collision, Science 189, no. 4201, 419-426.

Molnar, P., P. England, and J. Martinod (1993). Mantle dynamics, uplift of the Tibetan plateau and the Indian Monsoon, Rev. Geophys. 31, no. 4, 357-396.

Nelson, K. D., W. Zhao, L. D. Brown, J. Kuo, J. Chen, X. Liu, S. L. Klemperer, Y. Makovsky, R. Meissner, J. Mechie et al. (1996). Partially molten middle crust beneath southern Tibet: Synthesis of project INDEPTH results, Science 274, 1684-1688.

Owens, T., and G. Zandt (1997). Implications of crustal property variations for models of Tibetan plateau evolution, Nature 387, 37-43.

Pan, S., and F. Niu (2011). Large constrasts in crustal structure and composition between the Ordos plateau and the NE Tibetan plateau from receiver function analysis, Earth Planet. Sci. Lett. 303, nos. 3/4, 291-298.

Pearce, J., and H. Mei (1988). Volcanic rocks of the 1985 Tibet geotraverse: Lhasa to Golmud, Phil. Trans. Roy. Soc. London 327, no. 1594, 169-201.

Powell, C., and P. Conaghan (1975). Tectonic models of the Tibetan plateau, Geology 3, no. 12, 727-731.

Royden, L. H., B. C. Burchfiel, R. W. King, E. Wang, Z. Chen, F. Shen, and Y. Liu (1997). Surface deformation and lower crustal flow in eastern Tibet, Science 276, no. 5313, 788-790.

Royden, L. H., B. C. Burchfiel, and R. van der Hilst (2008). The geological evolution of the Tibetan plateau, Science 321, no. 5892, 1054-1058.

Shen, Y., D. Shi, X. Li, E. Sandvol, A. Li, Z. Zhang, H. Li, and X. Liang (2008). Initial report on the northeastern Tibetan plateau seismic experiment and study of the May 12, 2008, Wenchuan earthquake, Eos Trans. AGU 89, no. 53 (Fall Meet. Suppl.), Abstract U23B-66.

Tapponnier, P., and P. Molnar (1977). Active faulting and tectonics in China, J. Geophys. Res. 82, no. 20, 2905-2930.

Tapponnier, P., Z. Xu, F. Roger, B. Meyer, N. Arnaud, G. Wittlinger, and J. Yang (2001). Oblique stepwise rise and growth of the Tibet plateau, Science 294, no. 5547, 1671-1677. 
Tilmann, F., J. Ni, and INDEPTH Seismic Team (2003). Seismic imaging of the downwelling Indian lithosphere beneath central Tibet, Science $\mathbf{3 0 0}$, 1424-1427.

Unsworth, M., A. Jones, W. Wei, G. Marquis, S. Gokarn, and J. Spratt (2005). Crustal rheology of the Himalaya and southern Tibet from magnetotelluric data, Nature 438, 78-81.

Vergne, J., G. Wittlinger, V. Farra, and H. Su (2003). Evidence for upper crustal anisotropy in the Songpan-Ganze (northeastern Tibet) terrane, Geophys. Res. Lett. 30, no. 11, 1552-1555, doi: 10.1029/2002GL016847.

Vergne, J., G. Wittlinger, H. Qian, P. Tapponnier, G. Poupinet, M. Jiang, G. Herquel, and A. Paul (2002). Seismic evidence for stepwise thickening of the crust across the NE Tibetan plateau, Earth Planet. Sci. Lett. 203, no. 1, 25-53.

Wang, C., W. Chan, and W. D. Mooney (2003). Three-dimensional velocity structure of crust and upper mantle in southwestern China and its tectonic implications, J. Geophys. Res. 108, no. B9, 176-193, doi: 10.1029/2002JB001973.

Wang, C., W. Han, J. Wu, H. Lou, and W. Chan (2007). Crustal structure beneath the eastern margin of the Tibetan plateau and its tectonic implications, J. Geophys. Res. 112, no. B07307, doi: 10.1029/ 2005JB003873.

Wang, Q., P. Zhang, J. T. Freymueller, R. Bilham, K. M. Larson, X. Lai, X. You, Z. Niu, J. Wu, Y. Li, J. Liu, Z. Yang, and Q. Chen (2001). Presentday crustal deformation in China constrained by global positioning system measurements, Science 294, no. 5542, 574-577.

Wei, W., M. Unsworth, A. Jones, J. Booker, H. Tan, D. Nelson, L. Chen, S Li, K. Solon, P. Bedrosian, S. Jin, M. Deng, J. Ledo, D. Kay, and B. Roberts (2001). Detection of widespread fluids in the Tibetan crust by magnetotelluric studies, Science 292, 716-718.

Wessel, P., and W. H. F. Smith (1998). New, improved version of the generic mapping tools released, Eos Trans. AGU 79, no. 47, 579, doi: 10.1029/ 98EO00426.

Wittlinger, G., F. Masson, G. Poupinet, P. Tapponnier, M. Jiang, G. Herquel, J. Guilbert, U. Achauer, G. Xue, and D. Shi (1996). Seismic tomography of northern Tibet and Kunlun: Evidence for crustal blocks and mantle velocity contrasts, Earth Planet. Sci. Lett. 139, 263-279, doi: 10.1016/0012-821X(95)00235-5.

$\mathrm{Xu}$, Y., F. Liu, J. Liu, and H. Chen (2002). Crust and upper mantle structure beneath western China from $\mathrm{P}$ wave travel time tomography, J. Geophys. Res. 107, 2220, doi: 10.1029/2001JB000402.

Xu, Z. (1992). Orogenic Processes of the Songpan-Ganze Orogenic Belt of China, Geol. Press, Beijing, 1-190 (in Chinese).

Yang, Y., M. H. Ritzwoller, Y. Zheng, W. Shen, A. Levshin, and Z. Xie (2012). A synoptic view of the distribution and connectivity of the mid-crustal low velocity zone beneath Tibet, J. Geophys. Res. 117, no. B04303, doi: 10.1029/2011JB008810.

Yao, H., C. Beghein, and R. D. Van der Hilst (2008). Surface wave array tomography in SE Tibet from ambient seismic noise and two-station analysis:-II. Crustal and upper-mantle structure, Geophys. J. Int. 173, 205-219, doi: 10.1111/j.1365-246X.2007.03696.x.

Yin, A., and T. M. Harrison (2000). Geologic evolution of the HimalayanTibetan orogeny, Annu. Rev. Earth Planet. Sci. 28, 211-280.

Yue, H., J. Chen, E. Sandvol, J. Ni, T. Hearn, S. Zhou, Y. Feng, Z. Ge, A. Trujillo, Y. Wang, G. Jin, M. Jiang, Y. Tang, X. Liang, S. Wei, H. Wang, and W. Fan (2012). Lithospheric and upper mantle structure of the northeastern Tibetan plateau, J. Geophys. Res. 117, no. B04303, doi: 10.1029/2011JB008545.

Zhang, C., D. Yang, H. Wang, Y. Takahashi, and H. Ye (2010). Neoproterozoic mafic-ultramafic layered intrusion in Quruqtagh of northeastern Tarim block, NW China: Two phases of mafic igneous activity with different mantle resources, Gondwana Res. 19, no. 1, 177-190, doi: 10.1016/j.gr.2010.03.012

Zhang, P., Z. Shen, M. Wang, W. Gan, R. Burgmann, P. Molnar, Q. Wang, Z. Niu, J. Sun, J. Wu, H. Sun, and X. You (2004). Continous deformation of the Tibetan plateau from Global Positioning System data, Geology 32, no. 9, 809-812.
Zhang, Q., E. Sandvol, J. Ni, Y. Yang, and Y. Chen (2011). Rayleigh wave tomography of the northeastern margin of the Tibetan plateau, Earth Planet. Sci. Lett. 304, nos. 1/2, 103-112, doi: 10.1016/ j.epsl.2011.01.021.

Zhang, Z., S. Klemperer, Z. Bai, Y. Chen, and J. Teng (2011). Crustal structure of the Paleozoic Kunlun orogeny from an active-source seismic profile between Moba and Guide in East Tibet, China, Gondwana Res. 19, no. 4, 994-1007, doi: 10.1016/j.gr.2010.09.008.

Zhang, Z., X. Yuan, Y. Chen, X. Tian, R. Kind, and X. Li (2010). Seismic signature of the collision between the East Tibetan escape flow and the Sichuan basin, Earth Planet. Sci. Lett. 292, no. 3/4, 254-264.

Zhao, J., Q. Deng, and Z. Lu (2004). A review of the geophysical exploration studies on northwest China, in Progress in Seismological and Solid Earth Geophysical Researches in Mainland China, Y. T. Chen, J. W. Teng, R. Kan, and C. Y. Wang (Editors), Seismological Press, Beijing, 128-134 (in Chinese).

Zhao, W., and W. J. Morgan (1985). Uplift of Tibetan plateau, Tectonics 4, no. 4, 359-369.

Zhu, L., and D. V. Helmberger (1998). Moho offset across the northern margin of the Tibetan plateau, Science 281, 1170-1172.

Key Laboratory of Geo-detection (China University of Geosciences)

Ministry of Education

Beijing 100083, China

xinfuli@cugb.edu.cn

lih@cugb.edu.cn

(X.L., H.L.)

Graduate School of Oceanography

University of Rhode Island

Narragansett, Rhode Island 02882

yshen@gso.uri.edu

(Y.S.)

Seismological Bureau of Heibei Province

Shijiazhuang 050021, China

gongm@eq-he.ac.cn

(M.G.)

Institute of Mineral Resources

Chinese Academy of Geological Sciences

26 Baiwanzhuang Road

Beijing 100037, China

shidanian@cags.net.cn

(D.S.)

Department of Geological Sciences

University of Missouri

Columbia, Missouri 65211

sandvole@missouri.edu

(E.S.)

Earth and Atmospheric Sciences Department

University of Houston

Houston, Texas 77204-5007

ali2@mail.uh.edu

(A.L.)

Manuscript received 23 January 2013; Published Online 29 April 2014 